\title{
Universal Model of a Biomass Gasifier for Different Syngas Compositions
}

\author{
Andrej Pirc - Mihael Sekavčnik - Mitja Mori \\ University of Ljubljana, Faculty of Mechanical Engineering, Slovenia
}

This paper presents the theoretical and technical characteristics of biomass gasifiers. The modelling of a gasifier requires a linear system of equations that represents the mass and energy balances of the gasifier. Three variations with regard to a different syngas composition or the technology used are discussed. To analyse the energy system in full detail, all the peripheral units had to be modelled: the mill, the drying house, the oxygen production facility and the gas engine. The IPSEpro commercial code was used for gasifier and energy system modelling. A mathematical model of the complex energy system was used for the parametrical analysis of the biomass moisture, the biomass composition, the outlet syngas temperature and the operating regime's influence on the exergetic system efficiency. The results are shown in appropriate diagrams and are compared to the operating experience.

Keywords: gasifier, syngas composition, biomass, energy system, model

\section{O INTRODUCTION}

The widespread use of fossil fuels has led to higher prices of energy and pollution of the environment. It is therefore a good idea to use the primary sources of energy more efficiently and to increase the share of renewable (e.g. hydro, solar, wind), geothermal and sustainable energy sources (e.g. wood). Slovenia is a country where the amount of wood clearing is less than the extent of forest growth [1]. The primary sources of energy should be used mainly for the production of electricity and heat should be extracted from the process if required [2]. Large energy savings can be introduced by utilising the waste heat from this process. The majority of the residual biomass should not be used just for heating, but also to obtain electrical energy or even to produce synthetic fuels such as syngas or biofuel [3] to [5]. These fuels also allow for the use of more effective technologies, such as gas turbines, combined cycles, internal combustion engines or even fuel cell systems. One advantage of an energy system with a biomass gasifier is the possibility of having full compatibility with a decentralised energy network [7] and [8].

Fig. 1 is a schematic representation of the mass flows for a numerical model of a universal gasifier to produce syngas of different chemical compositions.

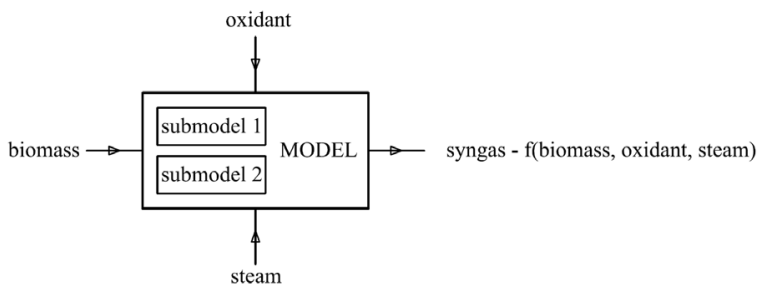

Fig. 1. Model of a universal gasifier
Syngas contains a mixture of methane, hydrogen and carbon monoxide in different proportions. A gasifier can also operate with different oxidants, like pure oxygen or air. The use of different oxidants leads to different syngas compositions [9] and consequently also impacts on the system's energy efficiency. This article is focused on the numerical modelling of syngas production using biomass. The following targets were set:

- the development of a system of equations based on:

- the stoichiometric relations of gasification,

- the heat and mass balances of the gasification model, including the submodels;

- the integration of a developed universal model of a gasifier into a broader energy system model with an internal combustion engine and the simulation of various gasification parameters.

\section{THEORETICAL BACKGROUND}

The production of syngas is determined by the substoichiometric combustion of solid fuel and the thermochemical decomposition of water. A certain portion of burned (fully oxidised) biomass is necessary to obtain sufficient heat to run the endothermic process of gasification. The products of complete combustion [10] contain nitrogen, water, carbon dioxide, ash and an excess amount of oxygen, whereas the products of gasification [11] contain methane, hydrogen, carbon monoxide, carbon dioxide and a small amount of ash and tar; in the present paper, all combustible contents (tar, char etc.) are assumed to be gasified as well.

Gasification operates with four main processes: wood drying, pyrolysis, sub-stoichiometric combustion and water reduction [9]. 
Firstly, wood biomass enters the drying process, with moisture decrease being important as some organic acids are discharged during the process of drying, which might shorten the lifetime of the gasifier [11].

Pyrolysis is the thermal decomposition of biomass occurring in the absence of oxygen [8]. It is a fundamental chemical reaction, which is the precursor of both the combustion and gasification processes. The products of biomass pyrolysis include biochar, bio-oil and gases, including methane, hydrogen, carbon monoxide and carbon dioxide. Depending on the thermal environment and the final temperature, pyrolysis will yield mainly biochar at low temperatures, i.e. less than $450{ }^{\circ} \mathrm{C}$, when the heating rate is quite slow, and mainly gases at high temperatures above $800{ }^{\circ} \mathrm{C}$, with rapid heating rates. At an intermediate temperature and under relatively high heating rates, the main product is bio-oil.

Due to the endothermic process of gasification, a particular volume of pyrolysis products must be burned. The combustion reactions are:

$$
\begin{aligned}
\mathrm{C}+1 / 2 \mathrm{O}_{2} & \rightarrow \mathrm{CO}-111 \mathrm{MJ} / \mathrm{kmol}, \\
\mathrm{CO}+1 / 2 \mathrm{O}_{2} & \rightarrow \mathrm{CO}_{2}-283 \mathrm{MJ} / \mathrm{kmol}, \\
\mathrm{H}_{2}+1 / 2 \mathrm{O}_{2} & \rightarrow \mathrm{H}_{2} \mathrm{O}-242 \mathrm{MJ} / \mathrm{kmol} .
\end{aligned}
$$

The combustion air consists of oxygen and unreactive nitrogen that causes ballistic heat losses.

During the reduction process, there are three main reactions: the water-gas reaction, the $\mathrm{CO}$-shift reaction and the steam-methane reforming reaction [9]:

$$
\begin{gathered}
\mathrm{C}+\mathrm{H}_{2} \mathrm{O} \leftrightarrow \mathrm{CO}+\mathrm{H}_{2}+131 \mathrm{MJ} / \mathrm{kmol}, \\
\mathrm{CO}+\mathrm{H}_{2} \mathrm{O} \leftrightarrow \mathrm{CO}_{2}+\mathrm{H}_{2}-41 \mathrm{MJ} / \mathrm{kmol}, \\
\mathrm{CH}_{4}+\mathrm{H}_{2} \mathrm{O} \leftrightarrow \mathrm{CO}+3 \mathrm{H}_{2}+206 \mathrm{MJ} / \mathrm{kmol} .
\end{gathered}
$$

The Eq. (2) describes reversible reactions. In general, the thermodynamic equilibrium of the reaction is achieved when the product formation rate is equal to the decomposition rate of the products into reactants [13]. Molar concentrations are described by the temperature-dependent equilibrium constant $K$ :

$$
\begin{aligned}
& A+B \leftrightarrow C+D, \\
& K=\frac{[\text { product_C }] \cdot\left[\text { product }_{-} D\right]}{[\text { reactant_A }] \cdot\left[\text { reactant } \_B\right]} .
\end{aligned}
$$

The total gas yield of biomass gasification is seriously affected by the constraints of many other operating variables [14] and [6]. An increase in the reaction temperature can lead to increases in gas production and decreases in the solid fraction. A better cracking reaction is achieved with a longer residence time of the volatile phase in the reactor. In addition, the decomposition of the tarry components is improved. Physical pretreatment is predominant for the production of the gas. When the particle size of the biomass feed is smaller, the gas yield increases. In contrast, moisture removal results in a slight decrease, while ash removal yields the same result. The heat transfer improvement exerts a positive effect on the decomposition of the tarry components, while the mass transfer improvement favours the char gasification reaction due to the increased contact between the char and steam surfaces. The gas yield is very sensitive to the temperature in the gasification reactor and also appears to be sensitive to the configuration of the reactor.

\section{NUMERICAL MODELLING}

The universal numerical model of the gasifier is represented by a system of linear equations. This numerical model was made to analyze the same system operation, depending on the most influential parameters. A universal numerical model can operate with different types of biofuel, different oxidants and consequently, produces a syngas with different chemical compositions. The transformation of wood to syngas is divided into four connected processes: wood drying, pyrolysis, incomplete combustion and water reduction. The proportion of an individual product is determined by the temperature, the pressure and the time duration of the process according to the Le Chatelier principle [13] and [19]. The oxidant supply is needed for sub-stoichiometric combustion, whereas the steam supply is needed for the whole reduction process. The model of the gasifier is designed to operate in three different modes and produces syngas with different chemical structures [16]:

1. Syngas consisting of carbon monoxide, methane, hydrogen and carbon dioxide.

2. Syngas consisting of hydrogen and carbon dioxide.

3. A third operating mode is to produce a mix of hydrogen and carbon monoxide in a ratio of one to seven. This specific mix can be used for methanol synthesis.

The model of the universal gasifier also makes possible calculations with different oxidants (oxygen or air). The factors associated with the oxidants used are shown in Table 1. These factors represent the basic values for defining the mass and heat flows of the process. 
Table 1. Factors for the oxidants used

\begin{tabular}{ccc}
\hline Oxidant & 0xygen & Air \\
\hline$a$ & 1 & $1 / 0.24$ \\
\hline$g$ & 0 & 0.76 \\
\hline
\end{tabular}

The factors for the operating mode show the basic values needed to determine the different operating modes and the chemical structure of the syngas in one common linear system of equations (Table 2).

Table 2. Factors for the operating mode

\begin{tabular}{cccc}
\hline Gas & $\mathrm{CO}, \mathrm{CH}_{4}, \mathrm{H}_{2}$ & $\mathrm{H}_{2}$ & $\mathrm{CO} / \mathrm{H}_{2}=7$ \\
\hline$b$ & 0 & 1 & 1 \\
\hline$k_{\text {red }}$ & 0 & 1 & 0.31 \\
\hline$c$ & 1 & 0 & 1 \\
\hline$d$ & 0 & 0 & 1 \\
\hline$e$ & 1 & 0 & 0
\end{tabular}

These factors are set for different syngas compositions in such a way that the appropriate terms in the Eqs. (6) to (11) are included and weighted.

Pyrolysis starts after wood biomass pre-warming. Due to their high reactivity, the products of pyrolysis combust first. The quantity of burned methane and hydrogen also depends on the total quantity of oxygen provided by the oxidant (burning air) and the chemical composition of the wood (wood containing oxygen). This has a direct influence on the chemical composition of the syngas and the heat flow needed for water reduction.

The heat flow of the burned pyrolysis products is therefore:

$$
\begin{aligned}
\dot{Q}_{\text {burn }} & =\dot{m}_{\mathrm{H} 2} \cdot w\left(\mathrm{H}_{2}\right)_{\text {burn }} \cdot H_{i}\left(\mathrm{H}_{2}\right)+ \\
& +\dot{m}_{\mathrm{CH} 4} \cdot w\left(\mathrm{CH}_{4}\right)_{\text {burn }} \cdot H_{i}\left(\mathrm{CH}_{4}\right)+ \\
& +\dot{m}_{C} \cdot w(\mathrm{C})_{\text {burn }} \cdot H_{i}(\mathrm{C}) .
\end{aligned}
$$

The index burn means burned, $H_{i}$ is the lower heating value and $\mathrm{w}$ is the mass fraction for each component.

The required oxidant mass flow equals:

$$
\dot{m}_{\text {oks }}=\left(\begin{array}{l}
\dot{m}_{\mathrm{CH} 4} \cdot w\left(\mathrm{CH}_{4}\right)_{\text {burn }} \cdot 2 \cdot \frac{M\left(\mathrm{O}_{2}\right)}{M\left(\mathrm{CH}_{4}\right)}+ \\
+\dot{m}_{\mathrm{H}} \cdot \frac{M\left(\mathrm{O}_{2}\right)}{M\left(\mathrm{H}_{2}\right)}+\dot{m}_{\mathrm{C}} \cdot w(\mathrm{C})_{\text {burn }} \cdot \frac{M\left(\mathrm{O}_{2}\right)}{M(\mathrm{C})}- \\
-\dot{m}_{\text {fuel }} \cdot w\left(\mathrm{O}_{2}\right)
\end{array}\right) \cdot a .
$$

$M$ is the molecular mass for each component, $a$ is the factor for the oxidant used and the index fuel means biomass fuel.
The water reduction heat flow is determined as follows:

$$
\begin{aligned}
& \dot{Q}_{\text {red }}=\dot{m}_{\mathrm{C}} \cdot\left(1-w(\mathrm{C})_{\text {burn }}\right) \cdot \dot{Q}_{\text {red }}(\mathrm{C})+ \\
& +\dot{m}_{\mathrm{CH} 4} \cdot\left(1-w\left(\mathrm{CH}_{4}\right)_{\text {burn }}\right) \cdot \dot{Q}_{\text {red }}\left(\mathrm{CH}_{4}\right) \cdot b- \\
& -\left(\begin{array}{l}
\dot{m}_{\mathrm{C}} \cdot\left(1-w(\mathrm{C})_{b u r n}\right) \cdot \frac{M(\mathrm{CO})}{M(\mathrm{C})}+ \\
+\dot{m}_{\mathrm{CH} 4} \cdot\left(1-w\left(\mathrm{CH}_{4}\right)_{b u r n}\right) \cdot \frac{M(\mathrm{CO})}{M\left(\mathrm{CH}_{4}\right)}
\end{array}\right) . \\
& k_{\text {red }} \cdot \dot{Q}_{\text {red }}(\mathrm{CO}) \text {, }
\end{aligned}
$$

where $b$ stands for the factor of the operating mode and the index red means the process of reduction.

The steam mass flow for the water reduction is calculated from the mass balance:

$$
\begin{aligned}
& \dot{m}_{\mathrm{H} 2 \mathrm{O}}=\dot{m}_{\mathrm{C}} \cdot\left(1-w(\mathrm{C})_{b u r n}\right) \cdot \frac{M\left(\mathrm{H}_{2} \mathrm{O}\right)}{M(\mathrm{C})}- \\
& -\dot{m}_{\mathrm{CH} 4} \cdot w\left(\mathrm{CH}_{4}\right)_{b u r n} \cdot 2 \cdot \frac{M\left(\mathrm{H}_{2} \mathrm{O}\right)}{M\left(\mathrm{CH}_{4}\right)}- \\
& -\dot{m}_{\mathrm{H} 2} \cdot \frac{M\left(\mathrm{H}_{2} \mathrm{O}\right)}{M\left(\mathrm{H}_{2}\right)}+ \\
& +\dot{m}_{\mathrm{CH} 4} \cdot\left(1-w\left(\mathrm{CH}_{4}\right)_{b u r n}\right) \cdot \frac{M\left(\mathrm{H}_{2} \mathrm{O}\right)}{M\left(\mathrm{CH}_{4}\right)} \cdot b+ \\
& +\left(\begin{array}{l}
\dot{m}_{\mathrm{C}} \cdot\left(1-w(\mathrm{C})_{b u r n}\right) \cdot \frac{M(\mathrm{CO})}{M(\mathrm{C})}+\dot{m}_{\mathrm{CH} 4} \cdot \\
\cdot\left(1-w\left(\mathrm{CH}_{4}\right)_{b u r n}\right) \cdot \frac{M(\mathrm{CO})}{M\left(\mathrm{CH}_{4}\right)}
\end{array}\right) . \\
& \cdot k_{\text {red }} \cdot \frac{M\left(\mathrm{H}_{2} \mathrm{O}\right)}{M(\mathrm{CO})} .
\end{aligned}
$$

The hydrogen mass flow produced by the water reduction is:

$$
\begin{gathered}
\dot{m}_{\mathrm{H} 2}=\dot{m}_{\mathrm{C}} \cdot\left(1-w(\mathrm{C})_{b u r n}\right) \cdot \frac{M\left(\mathrm{H}_{2}\right)}{M(\mathrm{C})}+ \\
+\dot{m}_{\mathrm{CH} 4} \cdot\left(1-w\left(\mathrm{CH}_{4}\right)_{\text {burn }}\right) \cdot 3 \cdot \frac{M\left(\mathrm{H}_{2}\right)}{M\left(\mathrm{CH}_{4}\right)} \cdot b+ \\
+\left(\begin{array}{l}
\dot{m}_{\mathrm{C}} \cdot\left(1-w(\mathrm{C})_{\text {burn }}\right) \cdot \frac{M(\mathrm{CO})}{M(\mathrm{C})}+ \\
+\dot{m}_{\mathrm{CH} 4} \cdot\left(1-w\left(\mathrm{CH}_{4}\right)_{b u r n}\right) \cdot \frac{M(\mathrm{CO})}{M\left(\mathrm{CH}_{4}\right)}
\end{array}\right) . \\
\cdot k_{\text {red }} \cdot \frac{M\left(\mathrm{H}_{2}\right)}{M(\mathrm{CO})} .
\end{gathered}
$$


The carbon monoxide mass flow equals:

$$
\begin{aligned}
\dot{m}_{\mathrm{CO}}= & \left(\begin{array}{l}
\dot{m}_{\mathrm{C}} \cdot\left(1-w(\mathrm{C})_{b u r n}\right) \cdot \frac{M(\mathrm{CO})}{M(\mathrm{C})} \cdot c+ \\
+\dot{m}_{\mathrm{CH} 4} \cdot\left(1-w\left(\mathrm{CH}_{4}\right)_{\text {burn }}\right) \cdot \frac{M(\mathrm{CO})}{M\left(\mathrm{CH}_{4}\right)}
\end{array}\right) \cdot(9) \\
& \cdot\left(1-k_{r e d}\right) \cdot d,
\end{aligned}
$$

where $c$ and $d$ stand for the factors of the operating mode.

The carbon dioxide mass flow is:

$$
\begin{aligned}
& \dot{m}_{\mathrm{CO} 2}=\dot{m}_{\mathrm{CH} 4} \cdot w\left(\mathrm{CH}_{4}\right)_{b u r n} \cdot \frac{M\left(\mathrm{CO}_{2}\right)}{M\left(\mathrm{CH}_{4}\right)}+ \\
& +\dot{m}_{\mathrm{C}} \cdot w(\mathrm{C})_{b u r n} \cdot \frac{M\left(\mathrm{CO}_{2}\right)}{M(\mathrm{C})}+ \\
& +\left(\begin{array}{l}
\dot{m}_{\mathrm{C}} \cdot\left(1-w(\mathrm{C})_{\text {burn }}\right) \cdot \frac{M(\mathrm{CO})}{M(\mathrm{C})}+ \\
+\dot{m}_{\mathrm{CH} 4} \cdot\left(1-w\left(\mathrm{CH}_{4}\right)_{\text {burn }}\right) \cdot \frac{M(\mathrm{CO})}{M\left(\mathrm{CH}_{4}\right)} \cdot k_{\text {red }}
\end{array}\right) . \\
& \cdot \frac{M\left(\mathrm{CO}_{2}\right)}{M(\mathrm{CO})} \cdot b .
\end{aligned}
$$

The final methane mass flow is:

$$
\dot{m}_{\mathrm{CH} 4, \text { fin }}=\dot{m}_{\mathrm{CH} 4} \cdot\left(1-w\left(\mathrm{CH}_{4}\right)_{\text {burn }}\right) \cdot e,
$$

where the index fin means final and $e$ is a factor to determine the operating mode.

The nitrogen mass flow is described in the next equation:

$$
\dot{m}_{\mathrm{N} 2}=\dot{m}_{o k s} \cdot g \text {, }
$$

where the index oks means the oxidant and $g$ is the factor of the used oxidant.

With regard to all the inlet and outlet energy flows [15], the following energy balance can be postulated:

$$
\begin{gathered}
\dot{m}_{f} \cdot h_{f}+\dot{m}_{\text {oks }} \cdot h(p, T)+\dot{m}_{\mathrm{H} 2 \mathrm{O}} \cdot h(p, T)+ \\
+\dot{Q}_{\text {burn }} \cdot\left(1-\eta_{\text {loss }}\right)-\dot{Q}_{\text {red }}-\dot{Q}_{\text {warm }}=\dot{m}_{s g} \cdot h(p, T),
\end{gathered}
$$

where $h$ is the enthalpy. The remaining indices have the following meanings: loss is the process of heat loss, warm is the preheating and $s g$ is the syngas.

\section{DESCRIPTION OF THE ENERGY SYSTEM}

The modelled units of the gasifier were introduced to the internal combustion engine (ICE) combined heat and power plant (CHP) model (Fig. 1). The power plant model was designed with the Simtech software Process Simulation Environment (PSE) [17], whereas particular submodels were made using Model Development Kit (MDK) [18]. Typical units, such as heat exchangers, pumps, compressors, the ICE and the generator, were taken from the program library. The humid wood is modelled as being first ground by a special mill, which is powered by an electric motor, and then dried in a drying house according to [1], see Fig. 4 . The dryer is a direct heat exchanger that mixes hot, dry air and humid, ground wood. The hot, dry air is prepared in a heat exchanger downstream from the internal combustion engine, using the heat of the ICE's exhaust gases. At the end of the process, moist and cooled air leaves the dryer. The dry and ground wood is taken to the gasifier, where the wood is pre-warmed to start pyrolysis. A certain proportion of the pyrolysis products are burned, with the remaining being reacted in a water-shift reduction. The oxidant is supplied for incomplete combustion. If the oxidant used is pure oxygen, the air is separated into nitrogen and oxygen by an air separation unit using the Linde technique [19]. The reduction process needs some steam supply. Both the oxidant and the steam are heated in regenerative heat exchangers [20]. The cooled syngas is combusted in the ICE, which is connected to the generator. The exhaust gases heat the air used for drying the humid wood. The cooling water of the internal combustion engine can be additionally used to prepare hot sanitary water or for other purposes [21].

The net electrical (exergy) efficiency depends on the particular constants of the sub-models and is defined using the following equation:

$$
\eta_{n e t}=\frac{P_{G}-P_{s u b}}{\dot{m}_{w} \cdot h_{w}}
$$

where the index $G$ means the generator of internal combustion engine, sub means subsidiary and $w$ means wood. The generator's electrical power (exergy flow) is reduced by the power consumption for the mill, pumps, compressors and air separation unit [2].

The total (energy) efficiency of the CHP power plant is defined as:

$$
\eta_{\text {total }}=\frac{P_{G}-P_{s u b}+\dot{Q}_{C W}}{\dot{m}_{w} \cdot h_{w}},
$$

where the index $C W$ means the engine's cooling water and $w$ means wood. It is obvious that terms in the numerator (Eq. (15)) represent the different kinds of energy flows. $\dot{Q}_{C W}$ can be used as a useful heating source in different applications and is therefore 


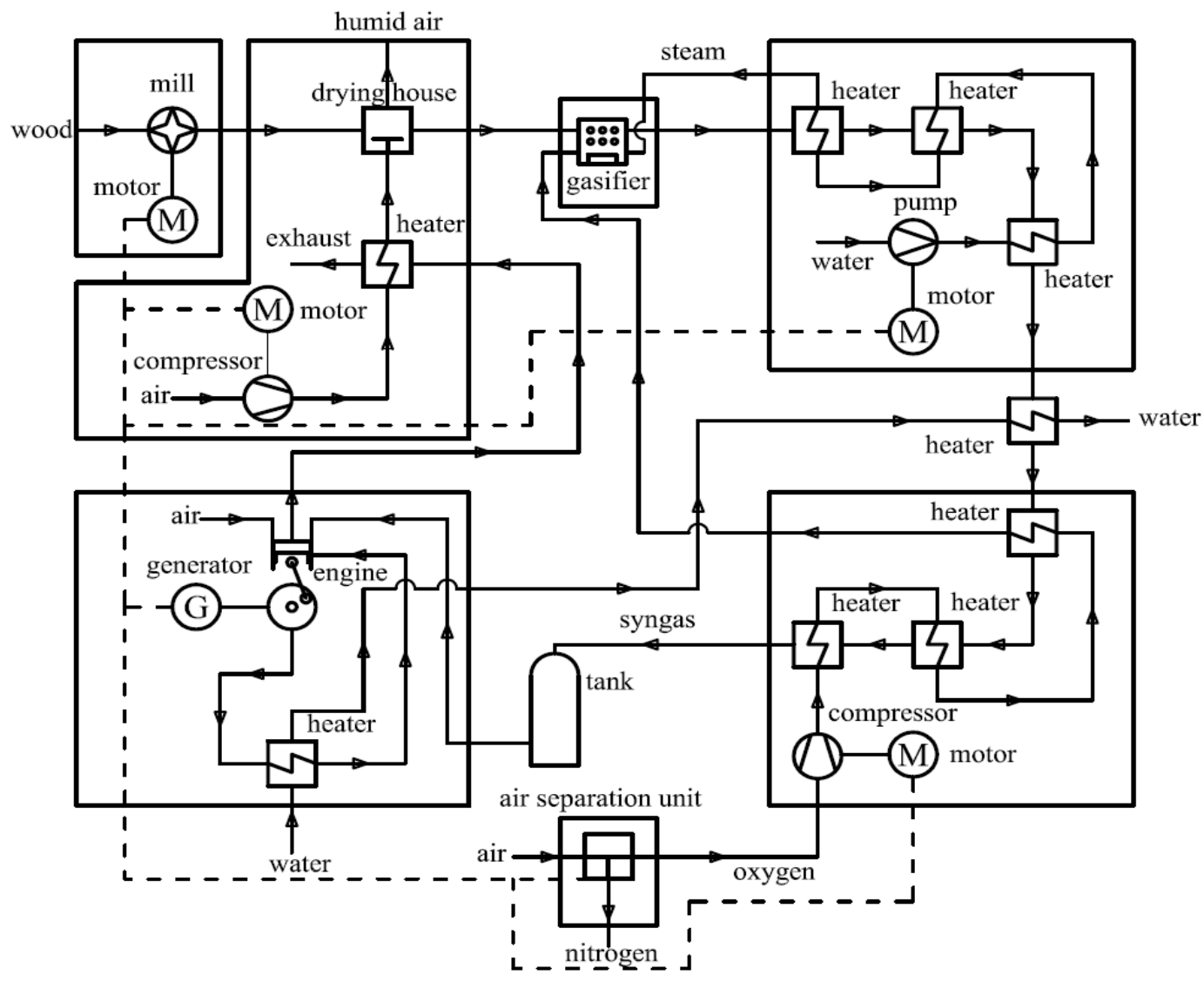

Fig. 2. Power plant scheme with the corresponding sub-models

treated the same as $P G$ regardless of the fact that their quality with respect to exergy content is considerably different.

The simulation shows that the total (energy) efficiency (sometimes called also CHP efficiency) of the system is $88 \%$, which is achieved in the following way: oxygen is the oxidant, wood moisture is $20 \%$ and the syngas contains methane, hydrogen, carbon monoxide.

\section{RESULTS}

Following a numerical simulation [17] of the power plant operation, an analysis of the influential factors was made. The factors which have the greatest influence on the net efficiency of the energy system are: type of wood, the wood moisture, the outlet temperature of the syngas and the operating mode.

\subsection{Type of Wood}

This analysis shows how the chemical composition of the wood influences the heating value of the syngas.
The diagram in Fig. 3 presents the results of the model for the following data:

- Wood moisture: $30 \%$.

- Oxidant: oxygen.

- Chemical composition of the syngas: methane, hydrogen, carbon monoxide.

- Mass fraction of burned methane: 0.595 .

- Parameter: type of wood (amount of hydrogen and carbon).

The chemical composition of the syngas was calculated according to previously adjusted inputs. Trees absorb carbon dioxide and change it into cellulose, hemicellulose and lignin in the process of photosynthesis. Different trees absorb different amounts of carbon dioxide over their lifetime; this is why different trees have different chemical compositions. Wood is made up primarily of the following compounds [10] and [22]:

- Cellulose 40 to $50 \%$.

- Lignin: 16 to $25 \%$ in hardwood, 23 to $33 \%$ in softwood.

- Hemicellulose: 20 to $30 \%$ in hardwood, 15 to $20 \%$ in softwood. 
- Other compounds (water, resins, etc.) 5 to $30 \%$.

- Minerals 0.1 to 3\%.

QWood with less hydrogen $(w=0.04)$

$\square$ Wood with more hydrogen $(w=0.045)$

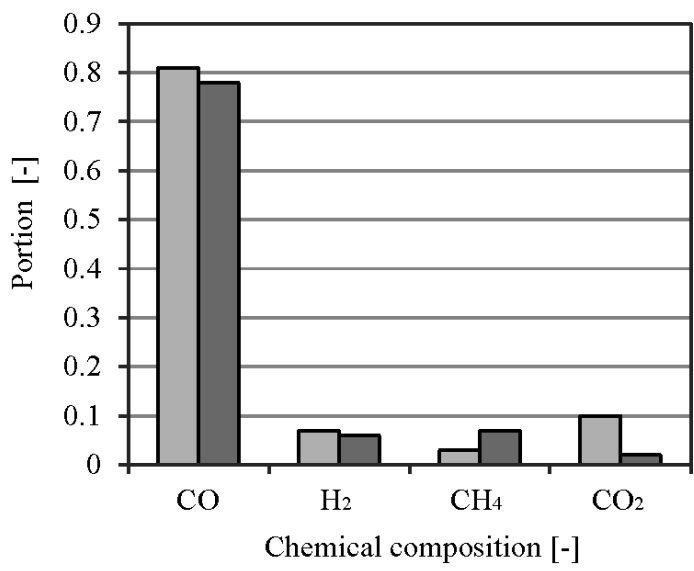

Fig. 3. Chemical composition of the syngas

A different chemical composition has an influence on the heating value of the wood and consequently, on the syngas. This result is confirmed by other authors [1], [3] and [12]. The syngas produced from wood with less hydrogen $(w=0.04)$ has a larger mass fraction of carbon monoxide and a smaller mass fraction of methane. The results for the syngas made from wood with more hydrogen $(w=0.045)$ are the opposite, as shown in Fig. 3.

\subsection{Wood Moisture}

Wood consists of carbon, hydrogen, oxygen and also some water, which lowers the net efficiency of the whole energy system. The diagrams in Figs. 4 and 5 show the results of calculations for the following data:

- Type of wood: hydrogen content $(w=0.045)$.

- Oxidant: oxygen.

- Chemical composition of the syngas: methane, hydrogen, carbon monoxide.

- Mass fraction of burned methane: 0.595.

- Parameter: wood moisture.

The mass fraction of water in fresh wood can be greater than $50 \%$. Using totally fresh wood would mean using a lot of energy to dry the wood before processing it in a gasifier. It is therefore advisable to allow fresh wood to lie for a certain period of time in an outdoor store [1]. In addition, due to its better reactivity, the wood should be first ground up, which leads to more efficient drying and a more stable and uniform gasification process [1].

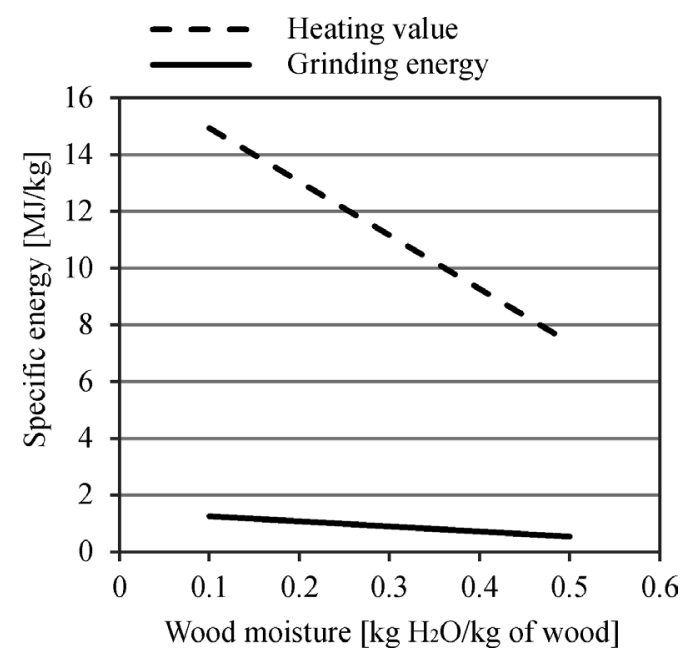

Fig. 4. Correlation between grinding energy, heating value of the wood and wood moisture

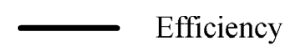

- - Mass fraction of burned methane

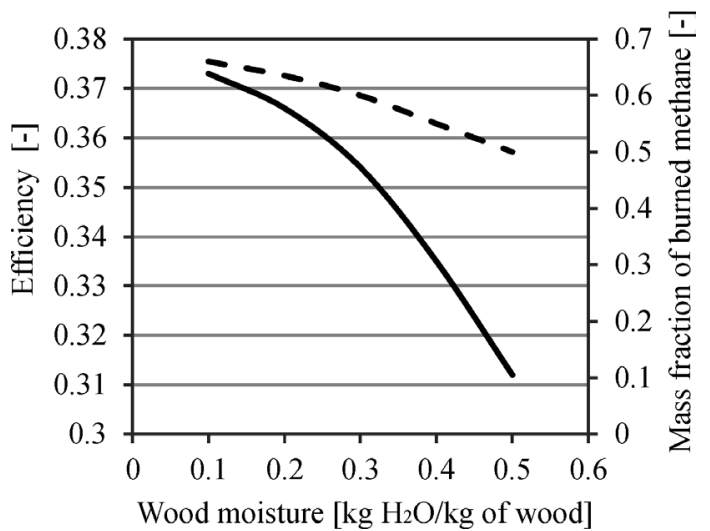

Fig. 5. Correlation between net efficiency, mass fraction of burned methane and wood moisture

Increasing the wood moisture reduces the net efficiency, a result obtained in the following research [1], [2] and [9]. The specific grinding energy decreases with the increased moisture of the wood [1], whereas the drying energy is significantly greater. The net efficiency of the system also decreased with a wood moisture increase because of the lower heating value of the fresh wood. In the case of wood that contains $50 \%$ moisture, all the mass flows into the gasifier are $50 \%$ lower with regard to the dry wood mass, which means less energy for oxidant and steam heating, pyrolysis and water reduction. Due to reduced energy consumption, the amount of burned methane is also smaller (Fig. 5). 


\subsection{Outlet Temperature of the Syngas}

The diagram in Fig. 6 shows the results of the model for the following data:

- Type of wood: hydrogen content $(w=0.045)$.

- Wood moisture: $30 \%$.

- Chemical composition of the syngas: methane, hydrogen, carbon monoxide.

- Oxidant: oxygen.

- Parameter: mass fraction of burned methane.

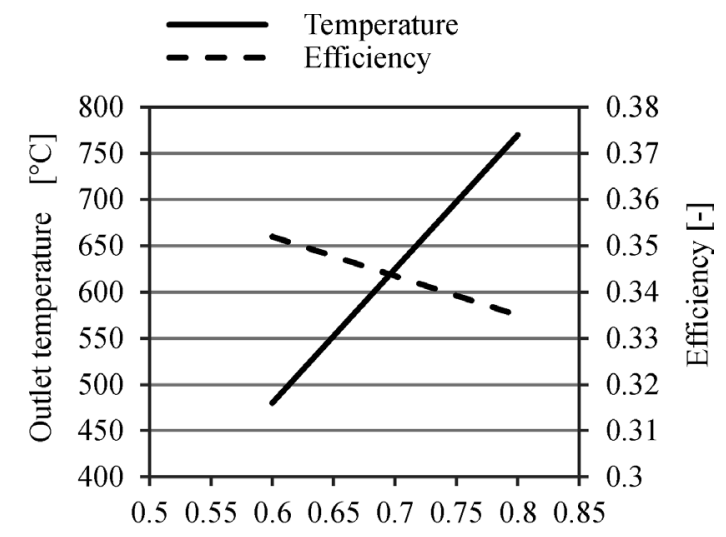

Mass fraction of burned methane [-]

Fig. 6. Correlation between the net efficiency, the outlet temperature of the syngas and the mass fraction of burned methane

Hydrogen and methane are the gaseous products of pyrolysis. In the presence of an oxidant, hydrogen burns immediately. The mass fraction of burned methane depends on the remaining amount of oxidant. The oxidant mass flow regulates the heat flow needed for endothermic reactions and the outlet temperature of the syngas. The mass fraction of burned methane should not be below 0.595 because a syngas with a low temperature cannot heat the oxidant and steam to process at a sufficient temperature. If the mass fraction of burned methane is larger than required, the temperature of the syngas increases. There is also a smaller amount of methane that can be burned in the internal combustion engine. This leads to a lower net efficiency.

\subsection{Operating Mode}

The chemical composition of the syngas also depends on the quantities of oxidant and steam supplied. The diagrams show the results of the model for the following data:

- Type of wood: hydrogen content $(w=0.045)$.
- Wood moisture: $30 \%$.

- Mass fraction of burned methane: 0.595 .

- Parameter: oxidant (oxygen, air) and chemical composition of wood.

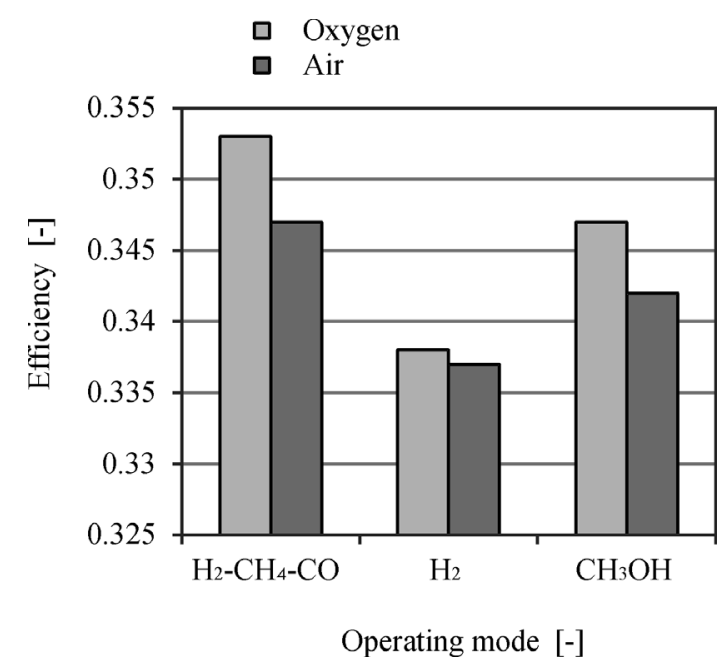

Fig. 7. Correlation between net efficiency and operating mode $\mathrm{aH}_{2} \quad \square \mathrm{CO} \quad \square \mathrm{CO}_{2} \quad \square \mathrm{CH}_{4}$

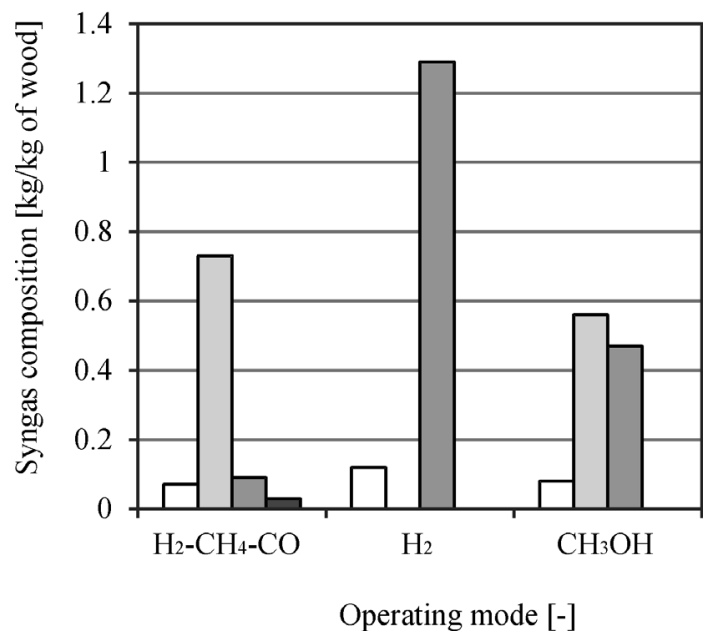

Fig. 8. Correlation between the syngas composition and the operating mode, using oxygen as an oxidant

When using oxygen as an oxidant, the system has to have an air separation unit, which separates the air into oxygen and nitrogen. The energy consumption of this unit is $250 \mathrm{kWh}$ per one tonne of oxygen produced [19]. Due to the energy consumption, a lower net efficiency is to be expected when operating with oxygen. But the use of air as an oxidant leads to larger mass flows connected to higher flow resistances, an increased heat flow to heat the oxidant, a larger mass 
fraction of burned methane needed, twice as large an installation with respect to size and material use [9], and finally a smaller total net efficiency [15] and [23], as shown in Fig. 7. The gasifier can produce a hydrogen-rich syngas. Our analysis only covered operating with an internal combustion engine. It would be sensible to convert this hydrogen to electricity in a fuel cell due to its better net efficiency [2].

The type of oxidant has an influence on the different chemical compositions of the syngas, too (Figs. 8 and 9). The values describing the syngas compositions are in the same range as achieved in practice [9], [23].

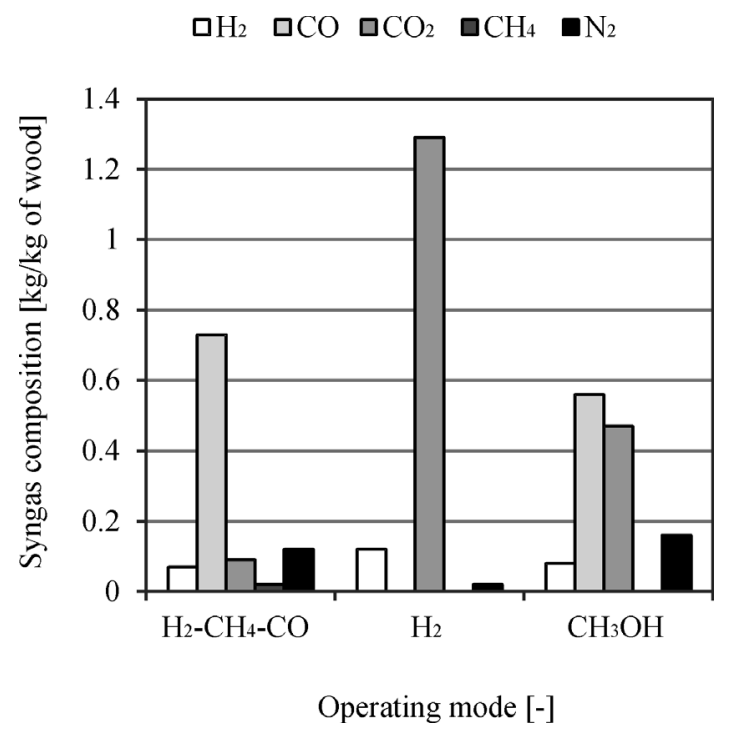

Fig. 9. Correlation between the syngas composition and the operating mode, using air as an oxidant

\section{CONCLUSIONS}

This paper presents a model of gasification and the most influential parameters. The energy and mass balances, the numerical model of the gasifier and the complete energy system were designed on the basis of a stoichiometric analysis of the gasifier. The numerical modelling and the simulation took place using the IPSEpro code. Based on the numerical model, the following results, which match well with previous research, experiments and practice, were obtained:

- The simulation of the operating gasifier shows that the most influential parameters are:

- the type of wood,

- the amount of wood moisture,

- the outlet temperature of the syngas,

- the type of oxidant (oxygen or air).
- The wood moisture has a major influence on the net efficiency.

- The highest net efficiency of $36.5 \%$ was achieved at $20 \%$ wood moisture. When working as combined heat and power production, the CHP efficiency increases up to $88 \%$.

- When the syngas consists of methane, hydrogen and carbon monoxide, the highest net efficiency of the system is achieved. Producing syngas for methanol synthesis is interesting due to its use in a mobile technique. The lowest net efficiency of gasification is achieved when producing a hydrogen-rich syngas; this is because of water reduction, which is an endothermic reaction. It is sensible to use a hydrogen-rich syngas in fuel-cell systems.

- Using oxygen as an oxidant is efficient in all cases.

\section{ACKNOWLEDGEMENT}

The part of presented work has been accomplished within the Centre of Excellence for Low-Carbon Technologies (CO NOT), Slovenia.

\section{NOMENCLATURE}

$h \quad$ enthalpy $[\mathrm{kJ} / \mathrm{kg}]$

$H \quad$ heating value $[\mathrm{kJ} / \mathrm{kg}]$

$k \quad$ ratio of reduction [-]

$K$ temperature-dependent equilibrium constant $[-]$

$m \quad$ mass $[\mathrm{kg}]$

$M \quad$ molecular mass $[\mathrm{kg} / \mathrm{kmol}]$

$p \quad$ pressure [bar]

$P \quad$ power $[\mathrm{W}]$

$Q \quad$ heat [J]

$T$ temperature $\left[{ }^{\circ} \mathrm{K}\right]$

$w \quad$ portion [-]

Chemistry symbols and compounds

C carbon

$\mathrm{CO}$ carbon monoxide

$\mathrm{CO}_{2}$ carbon dioxide

$\mathrm{CH}_{3} \mathrm{OH}$ methanol

$\mathrm{CH}_{4}$ methane

$\mathrm{H}_{2} \quad$ hydrogen

$\mathrm{H}_{2} \mathrm{O}$ water

$\mathrm{N}_{2}$ nitrogen

$\mathrm{O}_{2} \quad$ oxygen

Greek Letters

$\eta \quad$ efficiency 


$\begin{array}{ll}\text { Subscripts } \\ \text { burn } & \text { burned } \\ \text { CHP } & \text { combined heat and power production } \\ \text { CW } & \text { cooling water } \\ f & \text { fuel } \\ \text { fin } & \text { final } \\ \text { G } & \text { generator } \\ \text { ICE } & \text { internal combustion engine } \\ \text { loss } & \text { loss } \\ \text { net } & \text { network } \\ \text { oks } & \text { oxidant } \\ \text { red } & \text { reduction } \\ \text { sg } & \text { syngas } \\ \text { sub } & \text { subsidiary } \\ \text { total } & \text { total/complete } \\ \text { w } & \text { wood } \\ \text { warm } & \text { pre-warming }\end{array}$

\section{REFERENCES}

[1] Golob, A. (1999). Farmers guide. Agricultural Publishing Slovenj Gradec, Ljubljana. (in Slovenian).

[2] Tuma, M., Sekavčnik, M. (2004). Energy systems. University of Ljubljana, Faculty for Mechanical Engineering, Ljubljana. (in Slovenian)

[3] Klass, D.L. (1998). Biomass for renewable energy, fuels and chemicals. Elsevier, London.

[4] Minteer, S. (2006). Alcoholic fuels. CRC Press, Berkeley, DOI:10.1201/9781420020700.

[5] Deublein, D., Steinhauser, A. (2008). Biogas from waste and renewable resources. Wiley-VCH, Weinheim, DOI:10.1002/9783527621705.

[6] Lotrič, A., Sekavčnik, M., Kunze, C., Spliethoff, H. (2011). Simulation of Water-Gas Shift Membrane Reactor for IGCC Plant with $\mathrm{CO} 2$ Capture. Strojniški vestnik - Journal of Mechanical Engineering, vol. 57, no. 12, p. 911-926 DOI:10.5545/sv-jme.2011.100.

[7] Kirjavainen, M., Sipila, K., Savola, T., Salomon, M., Alakangas, E. (2004). Small-scale biomass CHP technologies, Situation in Finland, Denmark and Sweden. Opet report 12, Espoo.

[8] Buragohain, B., Mahanta, P., Moholkar, V.S. (2010). Biomass gasification for decentralized power generation: The Indian perspective. Renewable and Sustainable Energy Reviews, vol. 14, p. 73-92.
[9] Highman, C., Van der Burt, M. (2008). Gasification. Elsevier Science, Burlington.

[10] Kraut, B. (2003). Kraut's engineering handbook. Littera picta, Ljubljana. (in Slovenian).

[11] Goswami, D.Y. (1986). Alternative Energy in Agriculture, CRC Press, vol. 2, p. 83-102, from http:// www.nariphaltan.org/gasbook.pdf accessed on 201204-26.

[12] Sangeeta, C., Anil, K. (2007). A review of fixed bed gasification systems for biomass. CIGR E-Journal, vol. 9, no. 5, from: www.cigrjournal.org/index.php/ Ejounral/article/view/960/954, accessed on 2010-0517.

[13] Brenčič, J., Lazarini, F. (1996). General and inorganic chemistry. DZS, Ljubljana. (in Slovenian)

[14] Chen, G., Andries, J., Luo, Z., Spliethoff, H. (2003). Biomass pyrolysis/gasification for gas production: the overall investigation of parametric effects. Energy Conversion and Management, vol. 44, p. 1875-1884, DOI:10.1016/S0196-8904(02)00188-7.

[15] Tuma, M., Sekavčnik, M. (2004). Energy machinery and equipment. University of Ljubljana, Faculty for Mechanical Engineering, Ljubljana. (in Slovenian)

[16] Haryanto, A.D., Fernando, S.O., Pordesimo, L., Adhikari, S. (2009). Upgrading of syngas derived from biomass gasification: A thermodynamic analysis. Biomass and bioenergy, vol. 33, p. 882-889, DOI:10.1016/j.biombioe.2009.01.010

[17] Simtech (2003). IPSEpro Process Simulator - guide book, Graz.

[18] Simtech (2003). IPSEpro Process Simulator - Model Development Kit user guide, Graz.

[19] Atkins, P.W., Frazer, M.J., Clugston, M.J., Jones, R.A.Y. (1997). Chemistry principles and applications. TZS, Ljubljana. (in Slovenian)

[20] Oprešnik, M. (1988). Thermodynamics of mixtures. University of Ljubljana, Faculty for Mechanical Engineering, Ljubljana. (in Slovenian)

[21] Pehnt, M., Cames, M., Fischer, C., Praetorius, B. (2005). Microcogeneration: towards decentralized energy systems. Springer Verlag, Berlin, Heidelberg.

[22] from: http://ezinearticles.com/ChemicalCompositionof-Wood, accessed on 2010-11-05.

[23] Dowaki, K., Mori, S., Fukushima, C., Asai, N. (2005). A comprehensive economic analysis of biomass gasificatiton systems. Electrical Engineering in Japan, vol. 153, no. 3, p. 52-63, DOI:10.1002/eej.20089. 